\begin{tabular}{ccc}
\hline & & \\
& Journal of Modern Economy \\
(ISSN:2577-8218)
\end{tabular}

\title{
Research on the Impact of Chinese Science and Technology Finance on Entrepreneurial Efficiency
}

\section{JIANG GAI, WANG LUAN FENG*}

Hubei University.

\section{ABSTRACT}

This paper is based on panel data of 30 provinces and cities in China from 2008 to 2017, The convergence of innovation *Correspondence to Author: efficiency is tested by $\sigma$ convergence and $\beta$ convergence test, Hubei University. Using stochastic frontier model and principal component analysis to analyze the impact of Chinese science and technology finance on entrepreneurial efficiency. The study found: Venture capital investment is more flexible than the output of entrepreneurial man-power investment, technology finance has a significant positive impact on entrepreneurial efficiency, but there is a problem of regional development imbalance. Convergence and divergence analysis found, the gap in entre-preneurial efficiency between the central, eastern and western regions is gradually narrow; Factors such as social capital, economic development level and foreign direct investment also have a positive impact on entrepreneurial efficiency. Finally, this paper WANG LUAN FENG also puts forward some suggestions on improv-ing the efficiency of entrepreneurship from the perspectives of upgrading science and technology financial services, developing science and technology financial innovation and entrepreneurial environment.

How to cite this article:

JIANG GAI, WANG LUAN FENG. Research on the Impact of Chinese Science and Technology Finance on Entrepreneurial Efficiency Journal of Modern Economy, $2019,2: 7$

\section{eScîPub}

eSciPub LLC, Houston, TX USA. Website: http://escipub.com/

Keywords: Fintech, Social capital, Entrepreneur efficiency, Conversion efficiency 


\section{Introduction}

After bidding farewell to the rapid growth in the 40 years of reform and opening up, the Chinese economy has entered a new normal of medium and high-speed growth, the driving force of economic development is driven by factors, investment, and innovation. Under the background of the new era of "mass entrepreneurship and innovation", innovation and entrepreneurship activities have received extensive attention, and the enthusiasm of mass entrepreneurship has been rising steadily, and the entrepreneurial activity has increased dramatically. Entrepreneurship is the process of verifying, implementing, and implementing innovative behavior in a commercial manner. Entrepreneurship requires entrepreneurs to organize, integrate, configure and utilize resources scientifically, rationally and effectively based on identifying and grasping opportunities. China has always attached importance to the supportive role of finance in entrepreneurship. At the 19th National People's Congress, it also emphasized the importance of strengthening enterprises' innovation and entrepreneurship to promote high-quality economic development, especially, improve the financial market system and adapt China's financial development to the development needs of China's current economic situation. Although there are many related researches on financial innovation in entrepreneurship, there are not many studies on the efficiency of entrepreneurial efficiency from the perspective of science and technology finance. This paper studies the impact and mechanism of entrepreneurial efficiency from the perspective of China's science and technology finance, thus contributing to how China's technology finance development can improve entrepreneurial efficiency.

\section{Literature review}

\subsection{Science and technology finance related literature}

The literature review related to science and technology finance includes the theoretical discussion of science and technology finance, the impact of technology finance on enterprise technology innovation and the three aspects of technology finance innovation. The theory of technology finance Schumpeter $(1912,1942)$ puts innovation at the center of understanding capitalism, because innovation must provide funding, Finance must also be the center of capitalist economic theory. Schumpeter (1928) also discovered the positive effects of financial instruments such as credit on technological innovation and economic development, and emphasized the importance of financial institutions for independent innovation. Stiglitz (1973) found that the root cause of financing problems in SMEs is the information asymmetry between SMEs and financial institutions, which is prone to moral hazard and adverse selection. Carlota Perez (2002) in the "Technology Revolution and Financial Capital", the early emergence of new technology is an explosive growth period, which will lead to great fluctuations and uncertainties in the economy. In order to obtain high profits, venture capitalists quickly invest in new technology fields, resulting in a high degree of coupling between financial capital and technological innovation. Zhao Chang wen (2009) and other researches have proposed a more precise definition of science and technology finance that has been recognized by some scholars: science and technology finance is a series of financial instruments, financial systems, financial policies and promoting the development of science and technology, the transformation of results and the development of high-tech industries. Peng Zhen Jiang (2013), Fang Han Ting (2015) and Liu Wei (2014) both studied the theory of science and technology finance, and believed that the essence of technology finance is one of the most important branches of innovation economics. Technology Finance Center is a special technology center or financial center; it includes technology companies, technological innovations, financial institutions, and financial resources.

Rajan (1998) believes that the development of the financial system will help the creation of 
emerging companies, and a good financial system can reduce the barriers for companies to obtain external financing. Myers (1984) proposed the financing order theory that technology startups in order to reduce financing costs. Auken $(2001 ;$ 2002) on Bootstrap financing theory founded by Bide (1992), found that private lending capital can effectively promote the financing of small and medium-sized technology enterprises. Huang Ji Zhong (2017) Based on the provincial panel data research of China's eastern, central, western and national high-tech industries from 2007 to 2016, the innovation efficiency of high-tech industries in different regions of China has been improved; the development of technology finance has been improved to some extent, innovation efficiency of hightech industries. In terms of technology and financial innovation, Kim Kaivanto and Paul, Stoneman (2007) pointed out that the government should formulate corresponding policies to promote financial innovation, make up for the shortcomings of resource allocation, and support the development of technology enterprises. J. Wong (2013) pointed out that the government should provide good development opportunities for technology companies and fosters a market environment to supports innovation and development. Xiao Long Jie (2014) and Chen Zhong Wei (2018) found through research that the supporting policies of technological innovation and financial integration are very important in the science and technology financial innovation development system.

\subsection{Entrepreneurial related literature}

The literature related to entrepreneurship is mainly from the perspectives of entrepreneurial opportunities, entrepreneurial financing, entrepreneurial intentions and entrepreneurial environment. Kirzner (1973) believes that finding opportunities is a key part of entrepreneurship. Steven (1989) and others believe that entrepreneurship is the process of seeking, discovering and utilizing business opportunities, and is not restricted by current controllable resources.
Gerard 2002) considers entrepreneurship to be the process by which society, organizations, and individuals discover and exploit opportunities. Wang Yu Shuai (2009) believes that entrepreneurial activities are crucial to economic growth and development. Ye Ying Hua (2009) and Zhang Jian (2017) found that entrepreneurial self-cognition is a mediator of personality traits, social resources and prior knowledge that influence entrepreneurial intentions. Huang Sheng (2013), Chen Quan (2015) and Zhou Jian Rong, Yao Jian Feng (2016), through research, believe that entrepreneurial financing difficulties and lack of financial services hinder the effectiveness of mass entrepreneurship, Therefore, it is necessary to establish an entrepreneurial financial system that is compatible with supporting entrepreneurship, that is, to vigorously develop a new inclusive financial model for service and entrepreneurship and to improve the construction of an entrepreneurial financial service platform, and to provide practical support for mass entrepreneurship and innovation.

\subsection{The impact of technology finance on en- trepreneurship}

The literature on the impact of technology finance on entrepreneurial behavior is mainly two aspects. The impact of technology finance on business entrepreneurship, financial services support for entrepreneurship. Demirguc \& Levine (2008) used cross-country data to show that in countries with high levels of financial development, the rate of new business generation is also higher, because a well-functioning financial system can help companies break down financing constraints and overcome market access restrictions to start a business, and innovative activities. Meghana (2011) and Hanna \& Bettina (2012) found that when an enterprise finances an innovative project with a financial intermediary, the expected investment income and investment risk of the innovative project will affect its financing availability and the innovation capability of the enterprise also determines the enterprise innovation project, the key factors for 
obtaining financing. Khoutem (2014), Nadauld \& Weisbach (2012) and Hsuan (2014) found that service innovation of financial intermediaries can promote the development of innovative technologies by promoting the transaction costs of enterprises in the financing process, thereby promoting the growth of the real economy. Li Shi Hua (2013) believes that promoting and improving the capital market construction led by venture capital can not only accelerate the formation of the science and technology innovation system, but also facilitate the concentration of factors and the transformation of scientific and technological achievements. Zhang Yu Xi (2015), Li Rui Jing (2017), Chen Gang (2015) and other scholars have found through a large amount of data analysis that financial development can alleviate the financing constraints of potential entrepreneurs, also promoting entrepreneurial activities and promoting technological innovation. However, the results of Liu Peng Cheng (2018) research and analysis show that the relationship between financial openness and individual entrepreneurship is negative, financial openness has no obvious inhibitory effect on individual entrepreneurship in developed countries, and it has significant inhibitory effect on individual entrepreneurship in developing countries.

\section{Model construction and data description 3.1 Analysis model}

This paper measures the entrepreneurial efficiency by constructing a stochastic frontier model and analyzes the impact of technology finance on entrepreneurial efficiency. Using a traditional panel SFA model: $y_{i t}=\alpha+x_{i t}^{T}+v_{i t}-$ $u_{i t}$, most of the stochastic frontier models used in the past to study such problems are the DEA analysis methods used in the model and measure efficiency. However, relevant scholars have shown through research that the SFA model will lead to biased efficiency estimates. Because different individual members have different frontiers of production, the factors that affect the output of individual heterogeneity are attributed to the "inefficiency item". Therefore, it is necessary to introduce individual heterogeneity into the model, so that the measurement result of entrepreneurial efficiency is more accurate. So build the model below:

$$
y_{i t}=\alpha_{i}+\beta x_{i t}^{T}+\theta_{i t}=\alpha_{i}+\beta x_{i t}^{T}+v_{i t}-u_{i t}
$$

Where $\alpha_{i}$ represents the unobservable heterogeneity of region I, in the leading edge production function $x_{i t}$ represents the entrepreneurial input variable $\ln X_{i t}, y_{i t}$ indicates the entrepreneurial output variable $\ln Y_{i t}, v_{i t}$ is a random interference term. According to the model needs, it is assumed to follow a normal distribution with a mean of 0 and independent of each other. $u_{i t}$ indicates technical inefficiency item, it refers to variables such as technology finance, which have unilateral distribution characteristics. In order to empirically analyze the impact of technology finance on entrepreneurial efficiency, this paper proposes:

$$
\begin{aligned}
u_{i t} \sim h\left(z_{i t}, \delta\right) \cdot & N^{+}\left(\mu, \sigma^{2}\right) \\
& =\exp \left(z_{i t}^{T} \delta\right) \cdot N^{+}\left(\mu, \exp \left(c_{u}\right)\right)
\end{aligned}
$$

Where $z_{i t}^{T}$ is the influencing factor vector that affects the inefficiency of entrepreneurship, $\delta$ represents the coefficient of the explanatory variable affecting the inefficiency term. $\mu$ is greater than or equal to $0, \sigma^{2}=\exp \left(c_{u}\right)$, the stochastic frontier model and its assumptions constitute the random frontier model of the fixed effect panel data. At the same time, the maximum likelihood estimation method is used to obtain the parameter estimation value of the model. By the following formula: $B E_{i t}=\exp \left(-\hat{u}_{i t}\right)$ $\hat{u}_{i t}=\mathrm{E}\left[u_{i t} \mid \hat{\varepsilon}_{i}\right]$, calculate estimates of entrepreneurial efficiency. Principal Component Analysis (PCA) is used to deal with the three indicators of technology financial structure (FC), technology financial scale (FS) and technology financial efficiency (FE). Data standardization of raw indicators, the correlation coefficient matrix $R$ is obtained from the normalized data matrix, the eigenvalues and eigenvectors of the $R$ matrix are obtained, and the principal components are synthesized to obtain the comprehensive evaluation value. In summary, building model (1) 
and model (2) as follows:

$$
\begin{aligned}
& C Y P 1_{i t}=c_{0}+c_{1} C Y I 1_{i t}+c_{2} C Y I 2_{i t}+c_{3} \text { Fintech }_{i t}+X_{i t}+v_{i t}-u_{i t} \\
& C Y P 2_{i t}=c_{0}+c_{1} C Y I 1_{i t}+c_{2} C Y I 2_{i t}+c_{3} \text { Fintech }_{i t}+X_{i t}+v_{i t}-u_{i t}
\end{aligned}
$$

3.2 Variable selection and data description

\subsubsection{Explained variable}

Interpreted variables include venture capital (CYI) and entrepreneurial output (CYP). CYI1 uses venture capital investment as the ratio of the registered capital of new private enterprises in China to the registered capital of private enterprises in the previous year. The CYI2 entrepreneurial manpower input is the ratio of the number of university students in China to the employed population. The number of college students conclude undergraduate, master and doctor. CYP1 is the ratio of the number of new private enterprises and self-employed households to the number of private enterprises and individual households in the previous year. CYP2 is the ratio of the value of new private enterprises to the total value of private enterprises in the previous year.

\subsubsection{Explanatory variables}

Science and technology finance includes three sub-variables, they are the technology finance structure (FC), the technology finance scale (FS) and the technology finance efficiency (FE). The FC is divided into government technology finance and market technology finance. The government science and technology finance uses the ratio of government financial technology investment to government fiscal expenditure. The market technology finance uses the ratio of total technology finance to GDP; the total amount of market technology finance is the sum of venture capital, commercial bank technology credit and technology market financing. FS is measured from two aspects: scientific research resources input and scientific research output. The ratio of scientific research resources, that is, the ratio of scientific and technological activities to the total population of the region, and the ratio of scientific research output, the number of patent grants and patent applications. The ratio of the total amount of technology loans of financial institutions in FE to the total deposits and loans of financial institutions.

\subsubsection{Control variable}

The government element (GOV) is expressed by the ratio of government-supported venture capital investment to total government financial expenditure. Resident element (RS) mainly refers to the living standard and living conditions of residents, which is expressed by the ratio of average income and expenditure of urban residents in one year. The degree of market openness (MP) is expressed by the ratio of total import and export trade to GDP in China. The level of economic development (EL) is measured by GDP growth rate. Foreign direct investment (FI) is expressed as the ratio of foreign direct investment to GDP. Social capital (SC) is quantified by the density of social groups, which is the number of social groups that exist for every 10,000 employed people. In summary, we have a table of variable definitions as follows:

Table 1 Variable description

\begin{tabular}{|c|c|c|c|l|}
\hline & Variable name & & symbol & \multicolumn{1}{c|}{ definition } \\
\hline \multirow{3}{*}{ CYI } & \multirow{3}{*}{ CY } & CYI1 & $\begin{array}{l}\text { Ratio of registered capital of newly added private en- } \\
\text { terprises in China to registered capital of private enter- } \\
\text { prises in the previous year }\end{array}$ \\
\cline { 3 - 5 } & CYP & CYI2 & $\begin{array}{l}\text { The ratio of the number of Chinese university students } \\
\text { to the employed population }\end{array}$ \\
\cline { 3 - 5 } & & CYP1 & $\begin{array}{l}\text { The ratio of new private enterprises and self-employed } \\
\text { households in China to the number of private enter- } \\
\text { prises and individual households in the previous year }\end{array}$ \\
\hline
\end{tabular}




\begin{tabular}{|c|c|c|c|}
\hline & & CYP2 & $\begin{array}{l}\text { The ratio of the value of new private enterprises in } \\
\text { China to the sum of the value of private enterprises in } \\
\text { the previous year }\end{array}$ \\
\hline \multirow{5}{*}{ Fintech } & \multirow[t]{2}{*}{ FC } & FC1 & $\begin{array}{l}\text { The ratio of the government's financial technology in- } \\
\text { vestment to the government's fiscal expenditure }\end{array}$ \\
\hline & & FC2 & $\begin{array}{l}\text { The ratio of total science and technology finance to } \\
\text { GDP in China }\end{array}$ \\
\hline & \multirow[t]{2}{*}{ FS } & FS1 & $\begin{array}{l}\text { The ratio of Chinese science and technology activities } \\
\text { personnel to the total population of the region }\end{array}$ \\
\hline & & FS2 & $\begin{array}{l}\text { The ratio of the number of patents granted in China to } \\
\text { the number of patent applications }\end{array}$ \\
\hline & FE & FE & $\begin{array}{l}\text { Ratio of total financial loans of Chinese financial insti- } \\
\text { tutions to total deposits and loans of financial institu- } \\
\text { tions }\end{array}$ \\
\hline \multirow{6}{*}{ Control } & GOV & GOV & $\begin{array}{l}\text { The Chinese government supports the ratio of venture } \\
\text { capital investment to total government financial ex- } \\
\text { penditure }\end{array}$ \\
\hline & RS & RS & $\begin{array}{l}\text { The ratio of average income and expenditure of Chi- } \\
\text { nese urban residents in one year }\end{array}$ \\
\hline & MP & MP & China's total import and export trade and GDP ratio \\
\hline & EL & EL & China's GDP growth rate \\
\hline & $\mathrm{FI}$ & $\mathrm{FI}$ & The ratio of foreign direct investment to GDP in China \\
\hline & SC & SC & $\begin{array}{l}\text { Number of social groups per } 10,000 \text { working people in } \\
\text { China }\end{array}$ \\
\hline
\end{tabular}

\subsection{The Data Sources}

This paper mainly uses relevant data from 2008 to 2017 for analysis and research. The main data are from China National Bureau of Statistics, China Statistical Yearbook, China Financial Statistical Yearbook, and China's High-tech Industry Statistics Yearbook, China Enterprise Statistical Yearbook, China Science and Technology Statistical Yearbook and China Financial Statistics Yearbook.

\section{Empirical analysis}

\subsection{The model estimation result}

In this paper, the maximum likelihood estimation method is used to estimate the stochastic frontier model. Model 1 refers to the model with CYP1 as the entrepreneurial output variable. Model 2 refers to the model with CYP2 as the entrepreneurial output variable. This paper uses traditional assumptions $\left(u_{i t} \sim N^{-}\left(\mu_{i t}, \sigma^{2}\right) \equiv\right.$ $\left.N^{-}\left(Z_{i t}^{T} \delta, \sigma^{2}\right)\right)$ when estimating model 2. Cu in model 1 did not pass the significance test, indicating that there is no null hypothesis rejecting $\mathrm{Cu}=0$. Therefore the inefficiency term in the model $\left(\sigma^{2}=\exp \left(c_{u}\right)=1\right)$. Since $\sigma^{\wedge} 2$ in Model 1 and Model 2 are not 0 , it indicates that the random frontier model is reasonable in this paper. From the model estimation results in Table 1, we find that the coefficients of venture capital input (CYI1) in Model 1 and Model 2 are both larger than the factors of Venture Capital Input (CYI2). CYI1 is more resilient than CYI2. In addition, the sum of the coefficients of CYI1 and CYI2 is greater than 1 , indicating that China's entrepreneurial development is in the stage of increasing 
scale. From the estimation of the entrepreneurial inefficient function model, we can see that the coefficients of Fintech are negative. This shows that technology finance has a negative impact on entrepreneurial inefficiency, that is, the impact of technology finance on entrepreneurial efficiency is positive. However, in Model 2 , Fintech's t-value is -0.715 and less than 2 . It does not pass the significance test, indicating that the impact of technology finance on entrepreneurial efficiency in the establishment stage of the enterprise is greater than the entrepreneurial efficiency of the enterprise in the growth stage. However, in Model 2, Fintech's t-value is -0.715 and less than 2 . It does not pass the significance test, indicating that the impact of technology finance on entrepreneurial efficiency in the establishment stage of the enterprise is greater than the entrepreneurial efficiency of the enterprise in the growth stage. Most of the variables in the control variables have negative coefficients, except that the coefficients of GOV and $\mathrm{FI}$ in Model 2 are positive. It means that the influence of government and foreign direct investment in the growth stage of enterprises and individual entrepreneurship is negative. This may be due to the fact that the government's support for venture enterprises and individuals in tax policy has not been implemented.

Table 2 Stochastic frontier model estimation results

\begin{tabular}{|c|c|c|}
\hline & Model (1) & Model (2) \\
\hline \multicolumn{3}{|c|}{ Leading edge production function } \\
\hline CYl1 & $\begin{array}{l}0.710^{\star *} \\
(2.922)\end{array}$ & $\begin{array}{c}0.840^{*} \\
(1.051)\end{array}$ \\
\hline CYI2 & $\begin{array}{c}0.386^{\star} \\
(6.096)\end{array}$ & $\begin{array}{c}0.354^{*} \\
(9.865)\end{array}$ \\
\hline Constant term & $\begin{array}{c}-6.210 \\
(-2.735)\end{array}$ & $\begin{array}{c}3.488 \\
(8.156)\end{array}$ \\
\hline \multicolumn{3}{|c|}{ Non-efficiency function } \\
\hline Fintech & $\begin{array}{l}-0.142^{\star *} \\
(-3.354)\end{array}$ & $\begin{array}{l}-0.137^{\star *} \\
(-0.715)\end{array}$ \\
\hline GOV & $\begin{array}{l}-0.137^{*} \\
(-3.161)\end{array}$ & $\begin{array}{c}0.186^{\star *} \\
(-2.423)\end{array}$ \\
\hline RS & $\begin{array}{l}-0.316^{\star} \\
(-3.645)\end{array}$ & $\begin{array}{l}-0.110^{\star *} \\
(-2.304)\end{array}$ \\
\hline MP & $\begin{array}{l}-0.174^{\star *} \\
(-0.149)\end{array}$ & $\begin{array}{l}-0.186^{\star *} \\
(-0.899)\end{array}$ \\
\hline EL & $\begin{array}{l}-0.181^{*} \\
(-0.291)\end{array}$ & $\begin{array}{c}-4.103 \\
(-1.597)\end{array}$ \\
\hline $\mathrm{FI}$ & $\begin{array}{c}-0.207^{*} \\
(-0.899)\end{array}$ & $\begin{array}{c}0.738 \\
(7.523)\end{array}$ \\
\hline SC & $\begin{array}{c}-0.153 \\
(-2.286)\end{array}$ & $\begin{array}{l}-8.369^{\star} \\
(-2.523)\end{array}$ \\
\hline$\mu$ (cons) & $\begin{array}{c}3.348^{\star *} \\
(14.316)\end{array}$ & $\begin{array}{c}0.817 \\
(-2.126)\end{array}$ \\
\hline
\end{tabular}




\begin{tabular}{|c|c|c|}
\hline $\mathrm{Cu}\left(\sigma^{2}\right)$ & $\begin{array}{c}-0.174^{\star} \\
(-1.597)\end{array}$ & $\begin{array}{l}0.964^{\star *} \\
(7.327)\end{array}$ \\
\hline Sample size & 310 & 310 \\
\hline Log & -223.634 & -165.683 \\
\hline
\end{tabular}

(Note: ${ }^{* * *},{ }^{* *},{ }^{*}$ are indicated at the level of $1 \%, 5 \%$, and $10 \%$, respectively, and t statistics in parentheses)

\subsection{Descriptive statistics of entrepreneurial efficiency}

From Table 2, we can see that the average value of entrepreneurial efficiency and value creation efficiency has decreased slightly from 2008 to 2009, and the entrepreneurial efficiency has been on the rise since 2009. The efficiency of entrepreneurship has increased from 0.232 in 2009 to 0.813 in 2017, and the efficiency of value creation has increased from 0.515 in 2009 to 0.874 in 2017 . From the standard deviation in the table, entrepreneurial efficiency is rising from 2009 to 2012, but it is declining after 2012, from 0.184 in 2012 to 0.122 in 2017. Compared with entrepreneurial efficiency, the downward trend of value creation efficiency is more obvious, from 0.286 in 2008 to 0.121 in 2017 . The reason for the change in standard deviation is due to the fact that the degree of science and technology finance in different regions is different, and the degree of impact of technology finance on entrepreneurship is different, which affects the distribution of efficiency. The economic development of different regions is different. There are differences in the availability and investment of venture capital. The awareness of entrepreneurs and individuals on entrepreneurship and the opportunities for entrepreneurship are also different. From the data collected, it is clear that the investment in venture capital and entrepreneurial manpower in the central and eastern regions is better than that in the western region, and the increase in the number of new private enterprises, new self-employed households and new private enterprises is increasing, better than the western region. From the perspective of coefficient of variation, both entrepreneurial efficiency and value creation efficiency show a downward trend. This shows that there is a certain convergence in the change of entrepreneurial efficiency in various regions. We can think that there is a $\sigma$ convergence in entrepreneurial efficiency. With the development of China's economy and the implementation of China's western development strategy, the gap between entrepreneurship efficiency and level in the western region and the central and eastern regions is gradually narrowing.

Table 3 Descriptive statistics of entrepreneurial efficiency

\begin{tabular}{|c|c|c|c|c|c|c|}
\hline \multirow{2}{*}{ Year } & \multicolumn{2}{|c|}{ Average value } & \multicolumn{2}{c|}{ Standard deviation } & \multicolumn{2}{c|}{ Coefficient of variation } \\
\cline { 2 - 7 } & $\begin{array}{c}\text { Business } \\
\text { efficiency }\end{array}$ & $\begin{array}{c}\text { Conver- } \\
\text { sion effi- } \\
\text { ciency }\end{array}$ & $\begin{array}{c}\text { Business } \\
\text { efficiency }\end{array}$ & $\begin{array}{c}\text { Conver- } \\
\text { sion effi- } \\
\text { ciency }\end{array}$ & $\begin{array}{c}\text { Business } \\
\text { efficiency }\end{array}$ & $\begin{array}{c}\text { Conver- } \\
\text { sion effi- } \\
\text { ciency }\end{array}$ \\
\hline 2008 & 0.316 & 0.523 & 0.128 & 0.286 & 0.405 & 0.547 \\
\hline 2009 & 0.232 & 0.515 & 0.062 & 0.147 & 0.267 & 0.285 \\
\hline 2010 & 0.332 & 0.523 & 0.135 & 0.139 & 0.407 & 0.266 \\
\hline 2011 & 0.426 & 0.637 & 0.152 & 0.133 & 0.357 & 0.209 \\
\hline 2012 & 0.476 & 0.717 & 0.184 & 0.129 & 0.387 & 0.180 \\
\hline 2013 & 0.558 & 0.802 & 0.156 & 0.128 & 0.280 & 0.160 \\
\hline 2014 & 0.689 & 0.824 & 0.147 & 0.092 & 0.213 & 0.112 \\
\hline 2015 & 0.769 & 0.833 & 0.132 & 0.076 & 0.172 & 0.091 \\
\hline 2016 & 0.793 & 0.846 & 0.125 & 0.126 & 0.158 & 0.149 \\
\hline
\end{tabular}




\subsection{Convergence analysis of entrepreneurial}

This paper uses the conditional $\beta$ convergence test and the absolute $\beta$ convergence test method to empirically analyze the convergence and divergence of entrepreneurial efficiency. The absolute beta convergence test uses the

$$
\begin{gathered}
\Delta \ln B E_{i t}=\mathrm{a}_{0}+\mathrm{a}_{1} \ln B E_{i 0}+\varphi_{i} \\
\ln B E_{i t}-\ln B E_{i, t-1}=\gamma_{i}+\alpha_{2} \ln B E_{i, t-1}+\omega_{i t}
\end{gathered}
$$

Where $\Delta \ln B E_{i t}$ represents the annual growth rate of entrepreneurial efficiency in the crosssectional analysis method. $B E_{i 0}$ Indicates the initial value of entrepreneurial efficiency, $\varphi_{i}$ is a random interference term, and $\gamma_{i}$ is an individual fixed effect. If the value of $a_{1}$ in model (3) is negative, indicating that there is absolute convergence in entrepreneurial efficiency. If the value of $\alpha_{2}$ in model (4) is negative, indicating that there is a conditional convergence of entrepreneurial efficiency, otherwise there is no conditional convergence. It can be seen from the estimation results of the absolute convergence test in Table 3 that the coefficients of $\ln B E_{i 0}$ are negative in both entrepreneurial efficiency and value creation efficiency. And its $t$ statistics have passed the significance test, indicating that there is absolute convergence in

\section{efficiency}

cross-sectional analysis method as the model (3). The panel analysis method used for the conditional $\beta$ convergence test is the model (4). The regression equation using the two test methods is as follows:

entrepreneurial efficiency. In the early stage of low entrepreneurial efficiency, the growth rate of entrepreneurial efficiency is relatively high, and the upside is very large. The estimation results of the conditional convergence test are shown in Table 4. The coefficients of $\ln B E_{i t-1}$ in both entrepreneurial efficiency and value creation efficiency are negative. And both are significant, indicating the conditional convergence of entrepreneurial efficiency. This further illustrates that technology finance has a positive impact on entrepreneurial efficiency. Under the conditions of technological finance development, the level of entrepreneurship in various regions has increased, and the regions gap with lower entrepreneurial efficiency and higher entrepreneurial efficiency are gradually shrinking.

Table 4 Estimation result of absolute convergence test

\begin{tabular}{|c|c|c|}
\hline variable & Business efficiency & Conversion efficiency \\
\hline & -0.165 & -0.148 \\
$\ln B E_{i 0}$ & $(-6.382)$ & $(-5.223)$ \\
\hline & -0.096 & -0.027 \\
Constant term & $(-2.614)$ & $(-3.554)$ \\
\hline Sample size & 30 & 30 \\
\hline$A R^{2}$ & 0.615 & 0.822 \\
\hline
\end{tabular}

(Note: ${ }^{* * *},{ }^{* *},{ }^{*}$ are indicated at the level of $1 \%, 5 \%$, and $10 \%$, respectively, and $t$ statistics in parentheses)

Table 5 Estimation result of conditional convergence test

\begin{tabular}{|c|c|c|}
\hline variable & Business efficiency & Conversion efficiency \\
\hline & -1.712 & -1.926 \\
$\ln B E_{i t-1}$ & $(-9.137)$ & $(-7.454)$ \\
\hline & 0.816 & 0.925 \\
Constant term & $(10.026)$ & $(11.380)$ \\
\hline
\end{tabular}

JME: https://escipub.com/journal-of-modern-economy/ 


\begin{tabular}{|c|c|c|}
\hline Sample size & 172 & 172 \\
\hline$A R^{2}$ & 0.328 & 0.225 \\
\hline
\end{tabular}

(Note: ${ }^{* * *},{ }^{* *},{ }^{*}$ are indicated at the level of $1 \%, 5 \%$, and $10 \%$, respectively, and $t$ statistics in parentheses

\subsection{Robustness test}

In order to enhance the reliability of the conclusions of this paper, this paper uses the robustness test to test the impact of technology finance on entrepreneurial efficiency. Explain

$$
C Y P_{i t}=\beta_{0}+\beta_{1} C Y I_{i t}+\beta_{2} \text { Fintech }_{i t}+\beta_{3} \text { Control }_{i t}+u_{i t}
$$

Where $C Y P_{i t}$ indicates the entrepreneurial input variable, Control Cit $_{\text {is }}$ the control variable, Fintech $_{i t}$ is the main explanatory variable technology finance. In the test, the interaction items EAST $\times$ Fintech, Middle $\times$ Fintech and WEST $\times$ Fintech were added to compare the differences in the impact of technology finance on entrepreneurial efficiency in the central, eastern and western regions. The test results are shown in Table 5. The coefficient of CYI2 entrepreneurial manpower input is smaller than the coefficient of CYI1 venture capital input. It can be seen that the elasticity coefficient of the impact of venture capital on entrepreneurial efficiency is larger, which is consistent with the results of the analysis in Table 1. The coefficient of Fintech Technology Finance is positive, and the $t$ value is significant, indicating that technology finance has a significant positive impact on the improvement of entrepreneurial efficiency. FI foreign direct investment, MP market openness and SC social capital coefficient are positive, explanatory variables and control variables in the inspection process which is used to test their impact on innovation efficiency. Establish the following test equation:

but the degree of market openness and social capital $t$ value is not significant, that is, it does not pass the significance test, which is contrary to the estimation result of Table 1. The impact of $\mathrm{RS}$ residents' revenue and expenditure ratio on the number of new companies in CYP1 is negative, but the impact on the value of CYP2's new business is positive. The economic development level of EL is positive for CYP1, while the coefficient for CYP2 is negative, indicating that the improvement of economic development is conducive to promoting people to start businesses. However, the impact on the value creation stage in the entrepreneurial process has a depressing effect. It may be due to the excessive level of economic development, which leads to many systems not being sound enough, thus affecting corporate financing and other issues. In summary, the test results in Table 5 basically support the empirical research conclusions of this paper, and also prove that the empirical results of this paper are robust.

Table 6 Robustness test result

\begin{tabular}{|c|c|c|c|c|}
\hline & \multicolumn{2}{|c|}{$\begin{array}{c}\text { CYP1 (Number of new compa- } \\
\text { nies) }\end{array}$} & \multicolumn{2}{c|}{ CYP2 (Add corporate value) } \\
\hline CYI1 & $0.093^{* *}$ & $0.101^{* *}$ & $0.606^{* *}$ & $0.586^{* *}$ \\
& $(2.303)$ & $(2.533)$ & $(1.368)$ & $(1.347)$ \\
\hline CYI2 & $0.025^{* *}$ & $0.028^{* *}$ & $0.292^{* * *}$ & $0.246^{* *}$ \\
& $(2.139)$ & $(2.328)$ & $(2.907)$ & $(3.141)$ \\
\hline Fintech & $0.325^{* * *}$ & $0.364^{* *}$ & 0.718 & 0.695 \\
& $(4.012)$ & $(4.413)$ & $(5.597)$ & $(5.048)$ \\
\hline GOV & $0.156^{*}$ & $0.174^{*}$ & $0.137^{*}$ & $0.099^{* *}$ \\
& $(3.086)$ & $(3.395)$ & $(3.460)$ & $(3.738)$ \\
\hline RS & -0.109 & $-0.122^{* * *}$ & 0.254 & 0.081 \\
& $(-0.531)$ & $(-0.584)$ & $(2.015)$ & $(2.177)$ \\
\hline
\end{tabular}




\begin{tabular}{|c|c|c|c|c|}
\hline MP & $\begin{array}{c}0.058 \\
(0.219)\end{array}$ & $\begin{array}{c}0.065^{* *} \\
(0.241)\end{array}$ & $\begin{array}{c}0.084^{*} \\
(1.524)\end{array}$ & $\begin{array}{c}0.770 \\
(1.246)\end{array}$ \\
\hline EL & $0.084^{* *}$ & 0.094 & $-0.429^{*}$ & -0.415 \\
& $(3.765)$ & $(4.142)$ & $(-1.768)$ & $(-1.910)$ \\
\hline FI & $0.097^{*}$ & 0.109 & $0.102^{* *}$ & 0.283 \\
& $(1.674)$ & $(1.841)$ & $(3.824)$ & $(3.132)$ \\
\hline SC & 0.453 & $0.507^{*}$ & 0.212 & $0.132^{* * *}$ \\
& $(0.758)$ & $(0.835)$ & $(0.644)$ & $(0.696)$ \\
\hline EAST×Fintech & $0.396^{* * *}$ & & & $0.552^{*}$ \\
& $(2.524)$ & & & $(3.011)$ \\
\hline Middle×Fintech & $0.0948^{* *}$ & & & $0.205^{* *}$ \\
& $(5.197)$ & & & $(2.815)$ \\
\hline WEST×Fintech & $0.244^{* * *}$ & & & 0.609 \\
& $(1.244)$ & & & $(1.132)$ \\
\hline
\end{tabular}

(Note: ${ }^{* * *},{ }^{* *},{ }^{*}$ are indicated at the level of $1 \%, 5 \%$, and $10 \%$, respectively, and $t$ statistics in parentheses

\section{Conclusions and recommendations}

This paper uses panel data from 30 provinces and cities from 2008 to 2017, using both stochastic frontier models and principal component analysis, randomly examined the impact of technology finance on entrepreneurial efficiency. Then the convergence of innovation efficiency is tested by $\sigma$ convergence and $\beta$ convergence test method, and the robustness of empirical analysis results is tested by robustness test method. The following conclusions are obtained by estimating the parameters of the sample:

(1) Compared with the entrepreneurial manpower input, the output elasticity of venture capital investment is greater. Due to China's special economic development system, capital is scarce relative to labor, and venture capital is the main factor affecting entrepreneurial efficiency.

(2) Technology finance has a significant positive impact on entrepreneurial efficiency. Whether it is entrepreneurial efficiency or value creation efficiency, its impact is significant. The development of science and technology finance promotes the improvement of entrepreneurial efficiency. But there is a problem of regional imbalances.

(3) From the analysis of convergence and divergence, it can be found that, in general, the gap in entrepreneurial efficiency in various regions is gradually narrowing. The value creation efficiency between the central, eastern and western regions is gradually shrinking. In this respect, the gap in economic development in the three regions is narrowing. On the other hand, technology finance has also significantly reduced the gap between entrepreneurial efficiency in various regions.

(4) The results of the robustness test confirm the empirical results of this paper. It also finds that social capital, economic development level and foreign direct investment also have certain positive effects on entrepreneurial efficiency. In summary, this paper proposes the following recommendations:

(1) From the perspective of the development of science and technology finance, there is still much room for improvement in the support of China's science and technology financial system for innovation and entrepreneurship. Chinese financial institutions should focus on innovation in financial services and financial products. Through reform and optimization of the science and technology financial system, improve the efficiency of the relevant departments of science and technology finance, and provide a good financing channel for individuals and enterprises to start businesses. So that China's 
science and technology finance development is better to support entrepreneurship.

(2) From the perspective of individuals and companies. Individuals should first develop their own entrepreneurial abilities, raise their entrepreneurial awareness, and take the initiative to start a business. In the process of entrepreneurship, enterprises should establish a management mechanism for the use of venture capital, so as to maximize the output of venture capital investment. It is also necessary to establish an entrepreneurial talent management mechanism. While vigorously introducing technical talents, it is necessary to establish an incentive mechanism to encourage existing scientific research personnel to research and develop new technological achievements. However, both the enterprise and the individual entrepreneurial process should take care of the risks of entrepreneurship while broadening their channels of financing.

(3) From a social perspective, it is reasonable to introduce foreign investors to invest in China to start a business. Encourage them to establish research bases in China, use and learn their technological achievements, achieve innovation and entrepreneurship, and at the same time drive employment in China.

(4) From the government's point of view, the government should create a business platform for enterprises and individuals, improve the innovation and entrepreneurship service system and support policies related to entrepreneurship. Such as tax breaks, provide a certain percentage of venture capital grants and so on, creating a good entrepreneurial environment and strengthen entrepreneurship education for businesses and individuals. At the same time, we should also adjust the pace of economic development, take the road of high-quality economic development, and match China's financial development with the speed of economic growth. To build a good foundation for China's economic development and the development of science and technology finance to help innovation and entrepreneurship, achieving China's "mass entrepreneurship, innovation" goal, the goal of entrepreneurship to promote employment and the goal of sustainable economic development.

\section{References}

1. Schumpeter $\mathrm{J} A$. the instability of capitalism [J]. 1928(38):366-386.

2. Rajan R, Zingales L. Financial dependence and growth [J]. The American Economic Review, 1998(88):211-215.

3. Meghan A. Firm innovation in emerging market: The Role of Finance, Governance, and Competition [J].The Journal of Financial and Quantitative Analysis, 2011(6):1545-1580.

4. Hanna H, Bettina P. the Review of Economics and Statistics [J]. 2012(4): 1126-1142.

5. Nadauld T, M Weisbach. Did securitization affect the cost of corporate debt? [J].2012(105):332-352.

6. Khoutem B, Thouraya B, Kamel H. Financial Development and Economic Growth: New Evidence from Tunisia [J].2014(36):883-898.

7. Massimo. Technological Districts and the Financing of Innovation[J]. 2015(3):77-83

8. Brown J, B. C. Petersen. Law, Stock Markets and Innovation [J].2013(68):1517-1549.

9. Hyina A, R. Samaniego. Technology and Financial Development [J].2011(43):899-921.

10. Hsuan P. H, X. Tian and Y. Xu. Financial Development and Innovation: Cross-country Evidence [J].2014(112):113-135.

11. Li Shi Hua. Study on the Positioning of Venture Capital in Science and Technology Finance [J].Science and Technology Progress and Policy, 2013(8):156-159.

12. Zhang $\mathrm{Yu} \mathrm{Xi}$. The effect of China's science and technology finance investment on scientific and technological innovation [J].Science Research, 2015(2):177-214.

13. Shen Kun Rong. Mechanism and Empirical Research on Financial Frictions Affecting Entrepreneurship [J].China Economic Issues, 2017(1):73-84.

14. Liu Peng Cheng. Research on the Influence of Financial Opening on Individual 
Entrepreneurship [J].Financial Development Research, 2018(5):50-55.

15. Chen Gang. How Finance Promotes Entrepreneurship: Scale Expansion or Diversified Subjects [J].Financial Economic Research, 2015(9):29-42.

16. Yin Zhi Chao. Financial knowledge, entrepreneurial decision-making and entrepreneurial motives [J].Manage the world, 2015(1):87-98.

17. Fang Han Ting. Analyzing of the Nature of Science and Technology Finance [J]. China Science and Technology Forum, 2015(5):0510.

18. Liu Wei. The Dilemma, System Barriers and Policy Innovation Orientation of China's Science and Technology Finance Development [J].Fujian Forum, 2014(1):56-65.

19. Peng Zhen Jiang. Summary of China's Science and Technology Finance Theory Research [J].Science and Technology Progress and Policy 2013(8):157-163.

20. Xiao Long Jie. Research on the Innovation and Development of Science and Technology Finance [J].Modern Management Science, 2014(9):66-77.

21. Chen Zhong Wei. International Comparison and Enlightenment of the Development of Science and Technology Finance [J].Scientific Management Research, 2018(4):92-97.

22. Han Jun Hua. The economic growth effect, operation mode and risk management path of science and technology financial innovation [J].Scientific Management Research, 2018(6):102-107.

23. Wang Yu Shuai. The Construction of Theoretical Framework of Entrepreneurial Policy and Its Improvement Measures-From the Perspective of Entrepreneurial Process [J]. Science and Technology Progress and Countermeasures, 2009(19):113-118.

24. Zhang Jian. Why do people start a business-A study on the influencing factors of risk, entrepreneurship and financial constraints [J]. Journal of Central University of Finance and Economics, 2017(8):65-77.
25. Chen Quan. An Empirical Study on College Students' Entrepreneurial Self-efficacy and Its Influencing Factors [J].Higher Education Management, 2015(9):116-122.

26. [26] Qian Yong Hong. Study on the Factors of Entrepreneurial Intention [J].Journal of Zhejiang University, 2007(4):145-153.

27. Huang Sheng. Research on the Influencing Factors and Internal Mechanism of International Entrepreneurship [J].Science and Science and Technology Management, 2013(4):110-118.

28. Liu Xin Zhi. Analysis of the Impact of Financial Support on Farmers' Entrepreneurship and Its Spatial Differences [J].Macroeconomic Research, 2017(11):139-150.

29. Lin Wei. The Government's Financial and Financial Policy Design Supporting the Development of Entrepreneurial Economy [J].Journal of Shanxi University of Finance and Economics, 2012(11):92-93.

30. Zhang Long Yao. Financial Constraints and Family Entrepreneurship [J].Financial Research, 2013(9):123-136.

31. Zhu Hong Gen. Financial environment, policy support and farmers' entrepreneurial willingness [J].China Rural Watch, 2013(5):24-36.

32. Zhang Long Yao. Financial Development, Family Entrepreneurship and Urban and Rural Residents' Income-An Empirical Analysis Based on Micro Perspective[J].China Rural Economy,2013(7):47-59.

33. Fan Xiang Mei. Research on Financial Inclusion, Entrepreneurial Choice and Fair Distribution of Income [J].China Soft Science, 2018(9):64-76.

34. Gan Yu. Family entrepreneurship and its urban-rural differences: the impact of financial differences [J]. Shanghai Economic Research, 2015(9):15-24.

35. Wang Shu Qiang. Study on the financing optimization model of entrepreneurial enterprises based on internet finance [J]. Industrial technology economy, 2017(11):139—147.

36. Zhang Wei. Research on the Key Influencing 
Factors and Mechanisms of Initial Entrepreneurship and Re-Entrepreneurship: Matching Opportunities, Resources and Capabilities [J]. Research and Development Management, 2012(6):116-126.

37. Ding Dong Hong. Study on the Influence of Risk Tendency on Individual Entrepreneurial Willingness [J].Journal of Management, artita 2016(2):229-239. 